\title{
The Efficiency of First Telemedicine Application of Fundus Photograph for the Diagnosis of Diabetic Retinopathy in Turkey
}

\author{
(1) Meltem Sertbas, 'ㅁ Ozden Ezgi Uner, ${ }^{2}$ (1) Yasar Sertbas,' (10 Serkan Elarslan, \\ (1) Rahime Gozkan, '(1) Melike Kotan,' (1) Asligul Ardic,, (1) Volkan Kızılay,, \\ (1) Banu Açıkalın, ${ }^{4}$ (1) Nalan Okuroglu'
}

'Department of Internal Medicine, Fatih Sultan Mehmet Training and Research Hospital, İstanbul, Turkey

${ }^{2}$ Department of Family Medicine, Fatih Sultan Mehmet Training and Research Hospital, İstanbul, Turkey ${ }^{3}$ Department of Internal Medicine,

Ümraniye Training and Research Hospital, İstanbul, Turkey

${ }^{4}$ Department of Ophtalmology, Fatih Sultan Mehmet Training and Research Hospital, İstanbul, Turkey

Submitted: 25.01.2021 Accepted: 19.02.2021

Correspondence: Yasar Sertbas, Fatih Sultan Mehmet Eğitim ve Araştırma Hastanesi, İç Hastalıkları Kliniği, İstanbul, Turkey

E-mail: yserzincan24@gmail.com

口ifing

Keywords: Diabetes; fundus photograph; telemedicine.

(e) This work is licensed under a Creative Commons

\begin{abstract}
Objective: Diabetic retinopathy is one of the most common causes of preventable and treatable blindness in adulthood. Systemic screening with regular eye examination can prevent vision loss and blindness related to diabetic retinopathy. Our study aimed to see the efficiency of telemedicine application of fundus photograph for the diagnosis of diabetic retinopathy.
\end{abstract}

Methods: We retrospectively compared the patients' follow-up situation for diabetic retinopathy screening from two different diabetic centers between January 2018 and January 2019. We recruited 3539 diabetic patients. Among these patients, 1883 of them were referred to ophthalmologist from the first diabetes center, which is located on the main campus of hospital and in the second center which is located away from the hospital, 1656 patients' digital photographs were taken. These images were transmitted through a telemedicine system to an expert ophthalmologist for evaluation.

Results: As a result of the study, we saw that only 933 of I 883 (49.5\%) patients had admitted to the ophthalmologist for retinopathy control. On the other hand, among the patients who were screened by a digital photograph with telemedicine method, almost all of the patients were evaluated (1589 of 1656) and only 67 (4\%) of them could not be evaluated due to imaging problems. It is obviously seen that in the second center much more people had been evaluated when compared to the first center (933 [49.5\%] vs. I 589 [96\%]; p<0.05).

Conclusion: Our study confirmed that the use of the retinal photographing intertwined with the telemedicine system should be used more widely into provide regular screening of diabetic retinopathy.

\section{INTRODUCTION}

Diabetic retinopathy (DR) is one of the major microvascular complications of diabetes mellitus (DM) with a prevalence ranging from $12 \%$ to $35 \% .^{[1,2]}$ In 2017 , it was estimated that $\mathbf{4 2 5}$ million adults have diabetes and among these patients, I49 million people worldwide have DR with 45 million vision-threatening DR. ${ }^{[3]}$ Although this is the most common cause of adult-onset blindness, systemic screening with regular eye examinations can prevent vision loss and blindness due to DR. ${ }^{[4]}$

Due to recommendations of the American Diabetes Association, an initial eye examination should be performed within 5 years after the onset of Type I DM and at the time of diagnosis for Type 2 diabetic patients. ${ }^{[5]}$ Although most guidelines recommend regular eye examinations; underestimation of the risks, time consumption to access screening, geographic, social, and economic factors as well as exceeding the capacity of ophthalmologists to perform the eye screening seem to be the main reasons for not complying with the guidelines. ${ }^{[6,7]}$

Classical methods of eye examination are direct ophthalmoscopy, indirect ophthalmoscopy, slit-lamp biomicroscopy, and fundus photograph (FP). Another approach for early evaluation and monitoring of patient data is the telemedicine system that ensures the transmission of medical data through electronic telecommunication to physicians at a distance. ${ }^{[8]}$ In our study, we aimed to compare the data of two groups of patients who were either referred from the outpatient clinic to the ophthalmologist for the 
routine retinopathy control as a first group or as the second group, whose retinal photographs were transmitted through the telemedicine system to the ophthalmologist for retinopathy evaluation.

\section{MATERIALS AND METHODS}

In our study, we retrospectively compared the clinical data of diabetic patients who were admitted to two different diabetes centers of Education and Research Hospital between January 2018 and January 2019. The first center is located on the main campus of the hospital, and patients are being recommended to apply to the ophthalmology clinic for the evaluation of annual retinopathy. The second center is located $10 \mathrm{~km}$ outside the hospital, and the patients' annual retinopathy scans are being carried out through the retinal camera and telemedicine system.

At the second center, after the request of eye evaluation, a FP is taken and the captured digital fundus image is being transmitted to the expert ophthalmologist by the way of the hospital information management system (HIMS). Afterward, the report of this photograph is transmitted to the diabetologist through HIMS. FPs were captured using a fully automated non-mydriatic digital fundus camera (Digital Retinography System [DRS]; Centervue SpA, Padova, Italy) with a field of view $45^{\circ} \times 40^{\circ}$ and 5 megapixel sensor with a resolution of $2592 \times 1944$ pixels. FPs were classified as no apparent retinopathy, non-proliferative DR (NPDR), and proliferative DR (PDR). ${ }^{[9]}$ Patients with positive screening and those without visible images were being referred to the full ophthalmological examination. This clinical study was approved by the Clinical Research Ethics Committee of Hospital with the number of 2020/4-6234.

\section{Statistical analysis}

Analyses were performed using Statistical Package for the Social Sciences version 22.0 for Windows. Data are ex- pressed as meantstandard deviation. One-sample Kolmogorov-Smirnov test was performed to assess the distribution of data. Numerical variables in different subjects were compared by t-test or Mann-Whitney U-test. Categorical variables were analyzed by the $\chi^{2}$ test. Probability values were two tailed, and $p<0.05$ was considered statistically significant.

\section{RESULTS}

In our study, we recruited 3539 diabetic patients (of these 3539 patients, 1883 patients were referred to an ophthalmologist and 1656 patients digital photograph were taken). The average age of the patients was $58.22 \pm$ I I.33 with the duration of diabetes $10.57 \pm 7.76$ years. From the first diabetes center, 1883 patients were referred to an ophthalmologist for yearly retinopathy screening. Follow-up retinal screening information was not available for 950 (50.5\%) patients in their hospital records. These patients were considered not to be evaluated by an ophthalmologist. On the other hand, 933 (49.5\%) patients had been controlled by an ophthalmologist.

Among 1656 patients whose retinopathy scanning were performed by the telemedicine approach with their retinal photographs, 67 (4\%) of them could not be graded due to imaging problem and low quality of photographs. When we compared the two groups of patients, it was clear that the patients who underwent retinal photographing were significantly more evaluated for DR by ophthalmologists $\left(\chi^{2}[\mathrm{I}, \mathrm{n}=3550]=937.93 \mathrm{I}, \mathrm{p}<0.0000 \mathrm{I}\right)($ Table I $)$.

Of these patients assessed by an ophthalmologist at two centers ( $n=2522), 473$ (18.8\%) of patients were considered to have DR, whereas 2049 patients were considered not having DR. Of the 473 (18.8\%) patients with DR, 40 I (15.9\%) were graded as NPDR and the remaining 72 (2.9\%) patients were graded as PDR. The ratio of having

Table I. Documented retinal screening results of patients

\begin{tabular}{lccc}
\hline Screening method of patients & Number of evaluated patients & Patient with no documentation & p \\
\hline Referred to ophthalmologist $(n=1883)$ & $933(49.5 \%)$ & $950(50.5 \%)$ & 0.00001 \\
Digitally screened $(n=1656)$ & $1589(96 \%)$ & $67(4 \%)$ & \\
\hline
\end{tabular}

Table 2. Characteristics of patients due to presence of retinopathy

\begin{tabular}{|c|c|c|c|c|c|c|}
\hline & \multicolumn{2}{|c|}{$\begin{array}{l}\text { I }^{\text {st }} \text { DM center } \\
\text { referred to ophthalmologist }\end{array}$} & \multicolumn{2}{|c|}{$\begin{array}{l}2^{\text {nd }} \text { DM center } \\
\text { digitally screened }\end{array}$} & \multicolumn{2}{|l|}{ Total } \\
\hline & Number of patients & $\%$ & Number of patients & $\%$ & Number of patients & $\%$ \\
\hline No DRP & 706 & 75.6 & 1343 & 84.5 & 2049 & 81.2 \\
\hline Patient with DRP & 227 & 24.3 & 246 & 15.5 & 473 & 18.8 \\
\hline NPDR & 182 & 19.5 & 219 & 13.7 & 401 & 15.9 \\
\hline PDR & 45 & 4.9 & 27 & 1.8 & 72 & 2.9 \\
\hline
\end{tabular}

DRP: Diabetic retinopathy; NPDR: Non proliferative diabetic retinopathy; PDR: Proliferative diabetic retinopathy. 
DR was higher in the first center compared to the second $(24.3 \%$ vs. $15.5 \%$; $p<0.05)$ which is away from the hospital (Table 2).

\section{DISCUSSION}

To the best of our knowledge, the diabetes center, which is far away, but linked to a hospital, is the first center that uses a telemedicine system for routine retinopathy screening in Turkey. The primary goal of this system is to overcome the problems of the diabetic patient to reach eye care professionals. In this study, we compared data from two diabetes centers, one of which has been using this system versus another one referring patients to an ophthalmologist.

Despite all the treatment methods that can prevent vision loss, DR remains one of the main causes of blindness in adults. People with diabetes are 25 times more likely to be blind than the general population. In various studies, it has been found that DR may not give any symptom even up to the stage of blindness. ${ }^{[10]}$ The most important factor here is early diagnosis with fundus examination. Fundus examination is an essential part of the diagnosis of DR, providing treatment on time as well as preventing visual loss. ${ }^{[2]}$

A study conducted for screening DR showed that 260 (30\%) of 836 diabetic patients never had eye control before. ${ }^{[1]}$ In another study, Taylor et al. ${ }^{[12]}$ had divided their patients into two separated groups, in the first group, they had taken a retinal photograph of all the patients (20I patients), and in the second group, they had referred 294 patients to the ophthalmologist for examination. Consequently, among the 294 patients, only 92 (31.3\%) patients consulted with the ophthalmologist. ${ }^{[12]}$ In their study, Gosheva et al. ${ }^{[13]}$ demonstrated that, despite the recommendations, only half of the patients had received the recommended screening for DR. In line with the previous studies, among the 1883 patients who were referred to the ophthalmology clinic, 933 (49.5\%) patients were examined by an ophthalmologist in our study. By the way, most patients $(n=950 ; 50.5 \%)$ have not contacted to an ophthalmologist for their routine screening.

Retinal photographs of 1656 patients were taken at the second diabetes center, which was far from the hospital, and $67(4 \%)$ of the retinal picture could not be evaluated. On the other hand, $96 \%$ of the pictures were classified and graded by an ophthalmologist. Following the evaluation, patients with retinopathy and the patients whose retinal images could not be evaluated for various reasons were referred to the hospital for an eye examination. In different studies, retinal photographs of patients with severe cataracts, glaucoma, traumatic injury, and a small pupil could not be obtained or graded. ${ }^{\left[{ }^{[-13]}\right.}$ Gosheva et al. ${ }^{[13]}$ in their study had used the same system with us (DRS Centervue) and got better quality images with a minimum diameter of $>3 \mathrm{~mm}$ pupil size. The proportion of photographs that could not be evaluated in the work of Kim et al. ${ }^{[10]}$ varied between $10 \%$ and $30 \%$, depending on the mydriatic appli- cation. They thought that poorer results might be due to the resolution of the camera. In their study, Kim claimed that better results of the study belonging to Fransen et al. ${ }^{[14]}$ were due to the resolution of the cameras which were $600 \times 800$ versus || $52 \times|| 52$. In this study, we used a DRS Centervue camera with a resolution of $2592 \times 1944$ pixels. With this camera, we obtained better results than the previous studies with $4 \%$ of unassessed retinal photos.

Although the overall prevalence of diabetes increases overtime, there has been a decrease in the prevalence of $D R$, particularly vision-threatening $D R \cdot{ }^{\left[{ }^{[5]}\right.}$ In their study, Romero-Aroca et al. ${ }^{[15]}$ had evaluated different studies for 14 years and observed a decrease in DR prevalence from $1993(39.41 \%)$ to 2006 (27.48\%). In the study by Massimo Porta et al., ${ }^{\left[{ }^{[9]}\right.}$ the overall prevalence for any stage of DR and PDR was $16.7 \%$ and $0.7 \%$, respectively. In another study from Spain, 108.723 patients had been screened and the prevalence of any kind of DR was $12.3 \%$ (NPDR: 10.8\%, severe NPDR: $0.86 \%$, PDR: $0.36 \%$, and DMO: $0.18 \%)^{[l]}$ In an analysis of 35 studies from 22,896 patients, the prevalence was $34.6 \%(95 \% \mathrm{Cl} 34.5-34.8)$ for any DR, $6.96 \%$ (6.87-7.04) for PDR, and 10.2\% (10.1-10.3) for vision-threatening retinopathy. ${ }^{[2]}$ Throughout our study $(n=2522)$, the prevalence of DR, NPDR, and PDR was as $18.8 \%, 15.9 \%$, and $2.9 \%$. The prevalence of DR in the center, which is located in the hospital, was higher than the second center, which is located outside the hospital $(n=227 / 933 ; 24.3 \%$ vs. $n=246 / 1589 ; 15.5 \%$ ). We attributed this difference to the fact that patients who were being followed up by the ophthalmologist with various eye complications in the hospital might prefer to be followed by the diabetes center located in the hospital.

\section{CONCLUSION}

Our study confirmed that to provide regular screening for $D R$, the use of retinal photograph associated with the telemedicine system should be used more widely.

Ethics Committee Approval

This study approved by the Fatih Sultan Menmet Training and Research Hospital Clinical Research Ethics Committee (Date: 27.05.2020, Decision No: 2020/4-6234).

Informed Consent

Retrospective study.

Peer-review

Internally peer-reviewed.

Authorship Contributions

Concept: Y.S., O.E.U.; Design: Y.S., M.S., R.G.; Supervision: S.E., V.K., A.A.; Fundings: Y.S., M.S.; Materials: A.O., B.A.; Data: Y.S., M.K. R.G.; Analysis: Y.S., V.K., S.E., M.S.; Literature search: Y.S., O.E.U., R.G.; Writing: Y.S., O.E.U., R.G.; Critical revision: N.O., Y.S.

Conflict of Interest

None declared. 


\section{REFERENCES}

1. Rodriguez-Poncelas A, Miravet-Jiménez S, Casellas A, Barrot-De La Puente JF, Franch-Nadal J, Lopez-Simarro F, et al. Prevalence of diabetic retinopathy in individuals with Type 2 diabetes who had recorded diabetic retinopathy from retinal photographs in Catalonia (Spain). Br J Ophthalmol 2015;99:1628-33.

2. Yau JW, Rogers SL, Kawasaki R, Lamoureux EL, Kowalski JW, Bek $\mathrm{T}$, et al. Global prevalence and major risk factors of diabetic retinopathy. Diabetes Care 2012;35:556-64.

3. Thomas RL, Halim S, Gurudas S, Sivaprasad S, Owens DR. IDF diabetes atlas: A review of studies utilising retinal photography on the global prevalence of diabetes related retinopathy between 2015 and 2018. Diabetes Res Clin Pract 2019;157:107840.

4. Early photocoagulation for diabetic retinopathy. ETDRS report number 9. Early treatment diabetic retinopathy study research group. Opthalmology 1991;98 Suppl 5:766-85.

5. American Diabetes Association. Standards of medical care in diabetes-2013. Diabetes Care 2013;36 Suppl 1:S11-66.

6. Delcourt C, Massin P, Rosilio M. Epidemiology of diabetic retinopathy: Expected vs reported prevalence of cases in the French population. Diabetes Metab 2009;35:431-8.

7. Massin P, Aubert JP, Erginay A, Bourovitch JC, Benmehidi A, BenMehidi A, et al. Screening for diabetic retinopathy: The first telemedical approach in a primary care setting in France. Diabetes Metab 2004;30:451-7.

8. Das T, Raman R, Ramasamy K, Rani PK. Telemedicine in diabetic retinopathy: Current status and future directions. Middle East Afr J
Ophthalmol 2015;22:174-8.

9. Porta M, Boscia F, Lanzetta P, Mannucci E, Menchini U, Simonelli F. Systematic screening of retinopathy in diabetes ( $\mathrm{REaD}$ project): $\mathrm{An}$ Italian implementation campaign. Eur J Ophthalmol 2017;27:17984.

10. Kim H, Lowery JC, Kurtz R. Accuracy of digital images for assessing diabetic retinopathy. J Diabetes Sci Technol 2007;1:531-9.

11. Massin P, Aubert JP, Erginay A, Bourovitch JC, Benmehidi A, Audran G, et al. Screening for diabetic retinopathy: The first telemedical approach in a primary care setting in France. Diabetes Metab 2004;30:451-7.

12. Taylor CR, Merin LM, Salunga AM, Hepworth JT, Crutcher TD, O'Day DM, et al. Improving diabetic retinopathy screening ratios using telemedicine-based digital retinal imaging technology: The Vine Hill study. Diabetes Care 2007;30:574-8.

13. Gosheva M, Klameth C, Norrenberg L, Clin L, Dietter J, Haq W, et al. Quality and learning curve of handheld versus stand-alone non-mydriatic cameras. Clin Ophthalmol 2017;11:1601-6.

14. Fransen SR, Leonard-Martin TC, Feuer WJ, Hildebrand PL, Inoveon Health Research Group. Clinical evaluation of patients with diabetic retinopathy: Accuracy of the inoveon diabetic retinopathy-3DT system. Ophthalmology 2002;109:595-601.

15. Romero-Aroca P, Fernández-Balart J, Baget-Bernaldiz M, Martinez-Salcedo I, Mendez Marin I, Salvat-Serra M, et al. Changes in the diabetic retinopathy epidemiology after 14 years in a population of Type 1 and 2 diabetic patients after the new diabetes mellitus diagnosis criteria and a more strict control of the patients. J Diabetes Complications 2009;23:229-38.

\section{Türkiye'de Fundus Fotoğrafının Illk Teletıp Uygulamasının Diyabetik Retinopati Tanısında Etkinliği}

Amaç: Diyabetik retinopati yetişkin çağda görülen önlenebilir ve tedavi edilebilen körlük nedenlerinin başında gelmektedir. Düzenli göz muayenesi ile sistemik tarama, diyabetik retinopatiye bağlı görme kaybını ve körlüğü önleyebilir. Çalışmamızda fundus fotoğrafının teletıp uyarlanmasının diyabetik retinopati tanısında etkinliğinin gösterilmesi amaçlanmıştır.

Gereç ve Yöntem: Ocak 20।8-Ocak 2019 tarihleri arasında iki farklı diyabet merkezindeki hastaların diyabetik retinopati için takip durumlarını geriye dönük olarak karşılaştırdık. Çalışmaya 3539 diyabetik hasta dahil edildi. Bu hastalardan I883'ü hastanenin ana kampüsünde yer alan ilk diyabet merkezinden göz doktoruna sevk edilmiştir ve hastaneden uzakta bulunan ikinci merkezdeki 1656 hastanın ise dijital fundus fotoğrafı çekilmiştir. Bu görüntüler, bir teletıp sistemi aracılığıyla değerlendirmek üzere uzman bir göz doktoruna iletilmiştir.

Bulgular: Çalışma sonucunda 1883 hastadan sadece 933 'ünün (\%49.5) retinopati kontrolü için göz doktoruna başvurduğunu gördük. Diğer yandan, teletıp yöntemi ile dijital fotoğrafla taranan hastaların tamamına yakını değerlendirildi (I656'nın I589'u) ve sadece 67'si (\%4) görüntüleme sorunları nedeniyle değerlendirilemedi. Açıkca görüldüğü üzere, ikinci merkezde birinci merkeze göre çok daha fazla kişi değerlendirilmiştir (933 [\%49.5] 1589 [\%96]; p<0.05).

Sonuç: Sonuç olarak çalışmamız, teletıp sistemine uyarlanmış retina fotoğraflama yönteminin diyabetik retinopatinin düzenli taramasını sağlamak için daha yaygın kullanılması gerektiğini ortaya koymaktadır.

Anahtar Sözcükler: Diyabet; fundus fofoğrafi; teletıp. 